\title{
NACIONALNI SKRINING MALIGNIH BOLESTI U REPUBLICI SRBIJI
}

\author{
Sandra Šipetić Grujičićc ${ }^{1}$ Dragan Miljuš², Nevenka Pavlović3
}

\author{
${ }^{1}$ Institut za epidemiologiju, Medicinski fakultet Univerziteta u Beogradu, Srbija \\ ${ }^{2}$ Institut za javno zdravlje Srbije „Dr Milan Jovanović Batut” \\ ${ }^{3}$ Gradski zavod za javno zdravlje, Beograd, Srbija
}

Sažetak

Skrining test je prelimirano otkrivanje neprepoznatih poremećaja zdravlja u presimptomatskoj fazi bolesti korišćenjem različitih postupaka (fizikalni pregled, laboratorijska procedura, upitnik itd.) koji mogu brzo i lako da se primene. Skrining testovi mogu da budu selektivni, oportunistički, multipli (multifazni) i masovni (organizovani). Organizovani (masovni) skrining predstavlja organizovano masovno pozivanje ciljne populacije na testiranje i tumačenje testova, praćeno kontrolom kvaliteta i izveštavanjem. Izvodi se na celokupnoj populaciji ili njenom većem delu. Obično se sprovodi u ciklusima od po nekoliko godina. Organizovani skrining testovi koji se, od decembra 2012. godine, sprovode u našoj zemlji su: citološki bris grlića materice (Pap test) za rano otkrivanje raka grlića materice, imunohemijski test na okultno krvarenje u stolici (iFOB test) za rano otkrivanje raka debelog creva, i mamografija za rano otkrivanje raka dojke. Organizovani skrining je organizaciono složen proces zbog čega će se postepeno primenjivati na sve većem broju teritorija Republike Srbije u skladu sa materijalnim i finansijskim mogućnostima i edukacijom zdravstvenih radnika. Ključni akteri organizovanog skrininga u našoj zemlji su: domovi zdravlja, instituti i zavodi za javno zdravlje, zdravstvene ustanove sekundarnog i tercijarnog nivoa, Republički fond za zdravstveno osiguranje i Ministarstvo zdravlja. Organizovani skrining je od ogromnog značaja za smanjenje incidence i mortaliteta od malignih tumora, ali je organizaciono veoma zahtevan što i potvrđuju do sada dobijeni rezultati skrininga. Neophodno je dalje raditi na osnaživanju organizovanog skrininga za rak dojke, rak grlića materice i rak debelog creva na područjima gde se skrining realizuje i uvesti ga na svim područjima naše zemlje gde postoje uslovi za njegovo sprovođenje. Osim toga, akcenat treba staviti na kontinuirano unošenje i slanje podataka u elektronsku bazu podataka organizovanog skrininga od strane svih učesnika u skrining programu, radi evaluacije kvaliteta izvođenja i procene efektivnosti organizovanog skrining programa.

Ključne reči: organizovani skrining, validnost, pouzdanost, prediktivna vrednost, pristrasnost, evaluacija, efektivnost.

\section{Nacionalna politika}

Od početka tranzicije u Republici Srbiji usvojeno je više akata (Zakon o zdravstvenoj zaštiti, 2005; Strategija za prevenciju i kontrolu hroničnih nezaraznih bolesti, 2008; i Nacionalni program borbe protiv raka, 2009) kojim se želelo uticati na smanjivanje obolevanja i umiranja od svih bolesti, uključujući i maligna oboljenja, kao i na produženje prosečnog trajanja života naše populacije [1$-3]$.

$\mathrm{Na}$ osnovu preporuka Svetske zdravstvene organizacije (SZO) i rezultata skrining programa drugih zemalja, Ministarstvo zdravlja Republike Srbije je, uz pomoć stručnih radnih grupa, izradilo program organizovanog skrininga za rak grlića materice, rak dojke i rak kolorektuma u našoj zemlji. Ovi programi su usvojeni od strane Vlade Republike Srbije i objavljeni su kao Uredbe o nacionalnim programima za prevenciju raka grlića materice (2008. godine), raka dojke (2009. godine) i kolorektalnog karcinoma (2009. godine) [4-6].

Uredbom je 2009. godine utvrđen Nacionalni program pod nazivom „Srbija protiv raka” i uređeno je sprovođenje zdravstvene zaštite kojom se obuhvataju aktivnosti na prevenciji raka [7]. Ciljevi ovog programa su redukcija broja novoobolelih i umrlih od malignih bolesti, poboljšanje ranog otkrivanja malignih oboljenja, unapređenje dijagnostike i lečenja malignih bolesti, unapređenje kvaliteta života obolelih od malignih bolesti i njihovih porodica, obezbeđivanje odgovarajućeg standarda usluga na svim nivoima zdravstvene zaštite i unapređenje naučnih istraživanja $\mathrm{u}$ onkologiji. $\mathrm{U}$ okviru organizovanog skrininga poseban akcenat je stavljen na podizanje svesti ljudi o značaju skrininga, poboljšanje kapaciteta zdravstvenih ustanova (obezbeđivanje dovoljnog broja obučenih kadrova i opreme), uspostavljanje adekvatnog sistema prikupljanja i upravljanja podacima skrininga i sprovodjenje kontrole kvaliteta usluga za prevenciju malignih tumora. $\mathrm{Za}$ ostvarivanje navedenih ciljeva programa odgovorna je cela zajednica. Njihova realizacija je moguća samo kroz multisektorsku saradnju i intersektorsko ulaganje u očuvanje i unapređenje zdravlja. Sveobuhvatan i integrisan pristup u borbi protiv raka podrazumeva planiranje, koordinaciju, praćenje i evaluaciju aktivnosti čime se doprinosi poboljšanju efikasnosti preduzetih mera i omogućava optimalno korišćenje 
raspoloživih resursa.

Unapređenje Nacionalnog pograma izvršeno je 2012/13. godine uz podršku Evropske unije i projekta „Podrška uvođenju Nacionalnog programa za borbu protiv raka u Srbiji“, stručnog tima saradnika i radne grupe pri Ministarstvu zdravlja [8-13]. Od decembra 2012. godine Republika Srbija je započela sa postepenim uvođenjem organizovanog decentralizovanog skrininga raka grlića materice, raka dojke i raka debelog creva. Izvršnu ulogu u sprovođenju organizovanog skrininga na području R. Srbije ima Nacionalna kancelarija za skrining raka pri Institutu za javno zdravlje Srbije „Dr Milan Jovanović Batut“.

\section{Skrining}

U okviru prirodnog toka bolesti razlikujemo presimptomatsku i kliničku fazu (slika 1). Interval od trenutka kada se bolest može otkriti skriningom do pojave prvih simptoma predstavlja detektibilnu presimptomatsku fazu [16-17]. U ovoj fazi bolesti može da postoji jedna ili više kritičnih tačaka [17]. Kritična tačka je trenutak do kojeg ranije otkrivanje bolesti daje bolji ishod. Ako je bolest izlečiva, izlečenje je moguće pre ove tačke, ali ne i posle nje. Tako npr. kod žena sa karcinomom dojke kritična tačka je trenutak od kojeg se bolest proširila u regionalne limfne žlezde. Ako se bolest leči pre date tačke prognoza je bolja nego posle nje. Sledeća kritična tačka kod osoba sa karcinomom dojke je od trenutka kada se bolest iz regionalnih limfnih žlezda proširila u druge delove tela. Prognoza bolesti je i dalje bolja kod postojanja regionalnih nego sistemskih metastaza. Kritična tačka je teorijski koncept. Obično nije moguče identifikovati kada je kritična tačka dosegnuta. Međutim, ona je od ogromne važnosti u skriningu, jer ako ne postoji bar jedna kritična tačka, onda je bespotrebno koristiti skrining.

\section{Nivoi prevencije}

U cilju prevencije malignih oboljenja treba razlikovati primarnu, sekundarnu i tercijarnu prevenciju (slika 1) [17]. Primarna prevencija podrazumeva sprečavanje nastanka bolesti redukcijom ili eliminisanjem izloženosti uzročnim faktorima rizika ili imunizacijom, odnosno označava intervencije pre nastanka bolesti. Sekundarna prevencija podrazumeva skrining, otkrivanje bolesti u ranoj fazi bolesti tj. u presimptomatskoj fazi bolesti (interval od nastanka bolesti do pojave kliničkih simptoma i znakova bolesti), i rano lečenje. Tercijarna prevencija odnosi se na lečenje bolesnih osoba u kliničkoj fazi bolesti u cilju prevencije komplikacija bolesti uključujući smrtni ishod. Ako želimo da otkrijemo bolest ra-

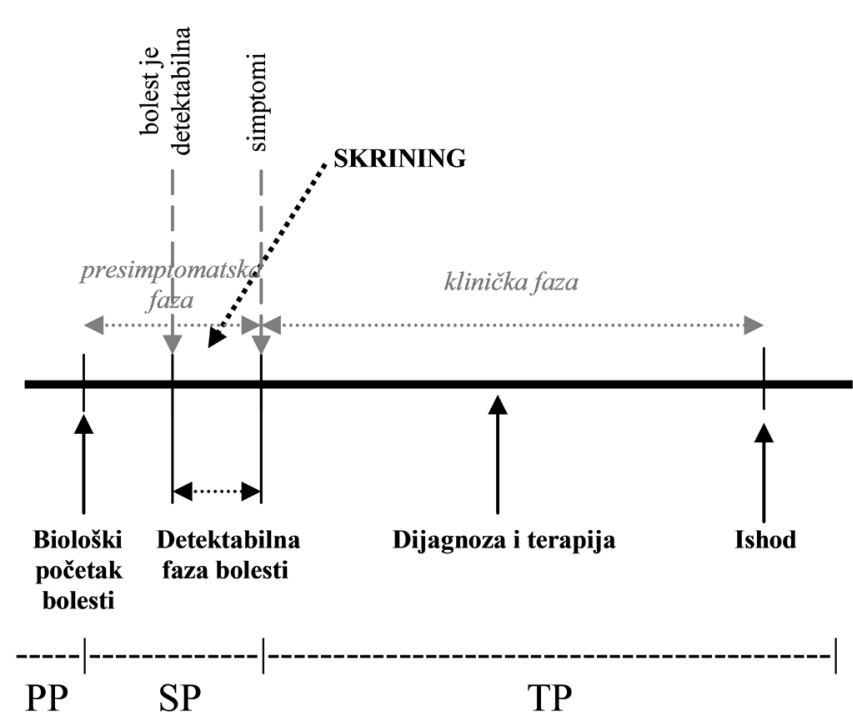

Slika 1. Prirodni tok bolesti i nivoi prevencije.

(PP - primarna prevencija, SP - sekundarna prevencija, TP - tercijarna prevencija)

(Modifikovano prema Gordisu) [17]

nije nego obično onda kroz programe zdravstvene edukacije treba da ohrabrimo osobe sa simptomima da što ranije zatraže pomoć od lekara. Međutim, najveći izazov je u identifikaciji obolelih bez kliničkih simptoma i znakova bolesti.

\section{Kriterijumi vezani za skrining test}

Svaki skrining test mora da ima zadovoljavajuću validnost, prediktivnu vrednost, mora da je pouzdan, jednostavan za izvođenje, bezbedan (minimalni neželjeni efekti), jeftin i što manje neugodan [14]. Validnost skrining testa je sposobnost testa da korektno klasifikuje ispitanike na osobe sa i bez oboljenja.Validnost ima dve komponente: specifičnost $(\mathrm{Sp})$ i senzitivnost $(\mathrm{Sn})$. Senzitivnost skrining testa se definiše kao sposobnost testa da korektno identifikuje obolele, a specifičnost kao sposobnost testa da korektno klasifikuje one koji oboljenje nemaju (tabela 1). Za određivanje Sn i Sp potrebno je da rezultate skrining testa uporedimo sa tzv. „zlatnim standardom", koji će nas uputiti u stvarno zdravstveno stanje ispitanika [15, 17]. „Zlatni standard“ može da bude neko detaljno kliničko ispitivanje, neka invazivna tehnika (biopsija) ili „protok vremena“. Upoređivanjem rezultata skrining testa sa rezultatima nekog "zlatnog standarda“ dobijaju se četiri grupe ispitanika. To su stvarno pozitivne, stvarno negativne, lažno pozitivne i lažno negativne osobe (tabela 1). Skrining test je idealan ukoliko se sa njim identifikuju kao pozitivni svi oboleli, a kao negativni svi zdravi (Sn i Sp su 100\%). U praksi ovakvi testovi su retki. 
Tabela 1. Poređenje rezultata skrining testa sa rezultatima „zlatnog standarda”.

\begin{tabular}{|c|l|l|}
\hline $\begin{array}{c}\text { Rezultati } \\
\text { skrining testa }\end{array}$ & \multicolumn{1}{|c|}{ Osobe sa oboljenjem } & \multicolumn{1}{|c|}{ Osobe bez oboljenja } \\
\hline Pozitivan & $\begin{array}{l}\text { Stvarno pozitivne osobe = Osobe koje } \\
\text { imaju oboljenje i koje su testom označene } \\
\text { kao pozitivne. }\end{array}$ & $\begin{array}{l}\text { Lažno pozitivne osobe = Osobe koje nemaju } \\
\text { oboljenje ali su testom označene kao } \\
\text { pozitivne. }\end{array}$ \\
\hline Negativan & $\begin{array}{l}\text { Lažno negativne osobe = Osobe koje } \\
\text { imaju oboljenje ali su testom označene kao } \\
\text { negativne. }\end{array}$ & $\begin{array}{l}\text { Stvarno negativne osobe = Osobe koje } \\
\text { nemaju oboljenje i koje su testom označene } \\
\text { kao negativne. }\end{array}$ \\
\hline
\end{tabular}

Važno je uočiti da postoji unakrsni odnos izmedju senzitivnosti i specifičnosti [15-17]. Ako se poveća senzitivnost spuštanjem granične vrednosti, dolazi do smanjenja specifičnosti, i obrnuto. Ujedno od izbora granične vrednosti zavisi broj lažno pozitivnih i negativnih rezultata testa. Obično se opredeljujemo za visoku senzitivnost testa kada je oboljenje sa ozbiljnom prognozom, a razvoj bolesti se može sprečiti ako se rano otkrije, kada bolest ima tendenciju brzog i lakog širenja, kada je u pitanju retko oboljenje ili kada su postupci za postavljanje dijagnoze jeftiniji i bez rizika. Nasuprot tome, skrining test treba da ima visoku specifičnost kada je u pitanju oboljenje sa velikom učestalošću javljanja, kada je naknadna dijagnostička procedura skupa i rizična ili kada se skrining sprovodi u celoj populaciji ili u njenom većem delu.

Prediktivna vrednost skrining testa može biti pozitivna i negativna [15-17]. Pozitivna prediktivna vrednost predstavlja verovatnoću da osoba koja je skriningom označena kao pozitivna zaista ima dato oboljenje. Negativna prediktivna vrednost predstavlja verovatnoću da osoba označena skriningom kao negativna, zaista nema dato oboljenje. Na prediktivnu vrednost skrining testa utiče prevalencija datog oboljenja u populaciji i specifičnost skrining testa. Ako se test sa istom senzitivnošću i specifičnošću koristi u populaciji gde je prevalencija oboljenja veća, onda je veća i pozitivna prediktivna vrednost tog testa, i obrnuto. Osim toga povećanjem specifičnosti skrining testa raste i njegova prediktivna vrednost.

Pouzdanost (ponovljivost, reproducibilnost) je sposobnost testa da daje iste rezultate pri ponovljenim ispitivanjima [17]. Ona zavisi od predmeta merenja, mernog instrumenta, unutarispitivačkih i međuispitivačkih variranja. Mnoge biološke karakteristike variraju u toku dužih ili kraćih vremenskih intervala (trenutne, dnevne, sezonske varijacije). Njihova vrednost zavisi i od načina merenja, vrste instrumenta, njegove baždarenosti i preciznosti. Unutarispitivačka variranja predstavljaju stepen neslaganja između dva ili više čitanja istog testa od strane jednog istraživača. Međuispitivačka variranja su stepen neslaganja između dva ili više istraživača koji čitaju iste testove. Do kojeg stepena se rezultati dva istraživača slažu potrebno je predstaviti kvantitativnim merama. Najbolji način za utvrđivanje saglasnosti me- đu istraživačima je tzv. kapa koeficijent. Kapa koeficijent manji od 0,40 predstavlja lošu, od 0,40 do 0,75 umerenu, a iznad 0,75 odličnu pouzdanost.

\section{Vrste skrining testova}

Skrining testovi mogu da budu selektivni, oportunistički, multipli (multifazni) i masovni (organizovani) $[16,17]$. Selektivni skrining se primenjuje na jasno definisanoj grupi ljudi koja je pod povećanim rizikom za neko oboljenje (članovi porodice sa urođenom hiperlipidemijom, radnici u industriji azbesta, itd.), ili čije oboljenje može da dovede do tragičnih posledica (mentalna nestabilnost vojnih lica, itd.). Multipli skrining predstavlja istovremenu primenu više skrining testova i može da bude sekvencijalni (dvofazni) i simultani (palpatorni pregled i mamografija, određjivanje glikemije našte i test opterećenja glukozom). Kod sekvencijalnih skrining testova prvo se izvodi jeftiniji, neinvazivniji i komforniji test, a potom se osobe označene pozitivno podvrgavaju drugom, skupljem, invazivnijem i neprijatnijem skrining testu. Ovaj postupak smanjuje broj lažno pozitivnih rezultata i samim tim broj osoba koje treba podvrći dijagnostičkoj proceduri. Pri izvođenju simultanih skrining testova osoba se označava kao pozitivna ako je pozitivna u svim, ili bilo kojem od izvedenih testova, a kao negativna ako je negativna prema rezultatima svih testova. Pri izvođenju simultanih testova povećava se ukupna senzitivnost a smanjuje specifičnost, dok u okviru sekvencijalnih testova raste specifičnost a smanjuje se senzitivnost. Oportunistički skrining se ograničava na osobe koje posećuju lekara iz nekog drugog razloga, nevezano od predmeta skrininga (PSA testu se npr. povrgavaju osobe koje se leče od osteoporoze). Ova vrsta skrininga ima brojne nedostatke, što je potvrđeno i u našoj zemlji posle njihovog decenijskog korišćenja. Obično je mali obuhvat ciljne populacije i osobe su nedovoljno informisane o značaju oportunističkog skininga. Pored toga, vrlo često ne postoje odgovarajuće kontrole kvaliteta edukacije zdravstvenih radnika i njihovog rada. Često, izveštaji nisu validni jer su bazirani na neadekvatno prikupljenim rezultatima skrininga. Organizovani (masovni) skrining predstavlja organizovano masovno pozivanje ciljne populacije na testiranje i tumačenje testova, praćeno 
kontrolom kvaliteta i izveštavanjem [14-17]. Izvodi se na celokupnoj populaciji ili njenim većim delom (npr. mamografija, Papanikolau test, itd.). Obično se sprovodi u ciklusima od po nekoliko godina. Organizovani skrining je organizaciono složen proces zbog čega će se u našoj zemlji postepeno primenjivati na sve većem broju teritorija u skladu sa materijalnim i finansijskim mogućnostima i edukacijom zdravstvenih radnika.

\section{Organizovani skrining u Republici Srbiji}

Organizovani skrining testovi koji se sprovode u našoj zemlji su: citološki bris grlića materice (Pap test) za rano otkrivanje raka grlića materice, imunohemijski test na okultno krvarenje u stolici (iFOB test) za rano otkrivanje raka debelog creva, i mamografija za rano otkrivanje raka dojke [8-13]. Ključni akteri organizovanog skrininga u našoj zemlji su: domovi zdravlja, instituti i zavodi za javno zdravlje, zdravstvene ustanove sekundarnog i tercijarnog nivoa, Republički fond za zdravstveno osiguranje i Ministarstvo zdravlja. Dom zdravlja je nosilac i izvodilac programa skrininga na teritoriji za koju je osnovan. Dom zdravlja formira Tim za koordinaciju skrininga, čiji je član i predstavnik regionalnog instituta/ zavoda za javno zdravlje. Nadležni institut/zavod za javno zdravlje obavlja koordinaciju sprovođenja skrininga (formira Tim za koordinaciju skrininga, koordinira i organizuje domove zdravlja i lokalnu zajednicu u cilju edukacije, motivacije i povećanja odziva lokalnog stanovništva na skrining, pruža pomoć pri izradi akcionih planova za sprovođenje skrininga u domovima zdravlja, prikuplja i ažurira podatke iz ustanova u kojima se sprovodi skrining (domovi zdravlja, bolnice) prema jedinstvenom obrascu, obrađuje te podatke i u vidu izveštaja prosleđuje ih jednom mesečno Kancelariji za prevenciju malignih bolesti). Dom zdravlja, priprema godišnji izveštaj o sprovedenom organizovanom skrining programu i dostavlja ga Kancelariji za prevenciju malignih bolesti.

U okviru organizovanog skrininga prvo se definiše ciljna grupa na osnovu liste osiguranika Republičkog zavoda za zdravstveno osiguranje i ostalih građana, pri čemu se poštuje Zakon o zaštiti podataka o ličnosti [8-13]. Skriningu se ne podvrgavaju lica koja se leče od malignog oboljenja za koji se sprovodi skrining, koja su u terminalnoj fazi bolesti usled nekog drugog oboljenja, ili koja ne mogu da obole od date bolesti. Spisak ciljne populacije i plan pozivanja za skrining pripremaju tim za koordinaciju skrininga raka u domu zdravlja i nadležni instituti/zavodi za javno zdravlje. Neophodno je omogućiti testiranje i van radnog vremena zbog zaposlenih. Lica koja se ne odazovu na prvi poziv ponovo se pozivaju u razmaku ne većem od 6 meseci. Pozivno pismo potreb- no je da sadrži poziv na skrining, telefon doma zdravlja u cilju zakazivanja termina za testiranje i informativni liflet. U slučaju da kontakt nije uspostavljen ni posle 6 meseci, dom zdravlja sprovodi neposredno pozivanje uz pozivno pismo. Ako se posle neposrednog pozivanja ne uspostavi kontakt, ta osoba se ponovo poziva u sledećem ciklusu skrininga. Učesnici skrininga potvrđuju učešće i termin testiranja telefonom, SMS-om, imejlom ili lično. Navedenog datuma osoba se sa pozivnim pismom javlja nadležnoj službi doma zdravlja. Zaduženi zdravstveni radnik je prihvata, uzima pozivno pismo, obavi evidentiranje i upućuje u odgovarajuću ambulantu određenu za skrining. Osoba potom potpisuje informisani pristanak za učešće u skriningu. Ukoliko je rezultat posle sprovedenog skrining testa negativan, osoba se o rezultatu testa može obavestiti telefonski, a u domu zdravlja može da preuzme pismeni izveštaj. Sve osobe sa pozitivnim nalazom pozivaju se u periodu ne dužem od tri nedelje i predlažu im se dalje dijagnostičke procedure po preporukama vodiča dobre kliničke prakse za dijagnostikovanje i lečenje datog malignog tumora.

\section{Evaluacija skrining programa}

U cilju procene efektivnosti skrining programa koriste se operativne (tabela 2) i ishodne mere (tabela 3) [17].

Tabela 2. Procena efektivnosti skrining programa pomoću operativnih mera [17].

1. Broj ljudi koji je povrgnut skriningu.

2. Procenat ciljne populacije koji je povrgnut skriningu i broj skrininga po osobi.

3. Određivanje prevalencije presimtomatske faze bolesti.

4. Ukupna cena skrining programa.

5. Cena po svakom otkrivenom obolelom slučaju.

6. Cena po otkrivenom prethodno nepoznatom obolelom.

7. Procenat pozitivno označenih osoba u skrining testu koji je podvrgnut dijagnostičkoj proceduri i terapiji.

8. Pozitivna prediktivna vrednost skrining testa.

Tabela 3. Procena efektivnosti skrining programa na osnovu mera ishoda [17].

1. Porast procenta slučajeva otkrivenih u ranoj fazi bolesti.

2. Opadanje broja umrlih među osobama podvrgnutim skriningu.

3. Opadanje letaliteta među osobama podvrgnutim skriningu.

4. Opadanje učestalosti komplikacija.

5. Smanjenje učestalosti recidiva i metastaza.

6. Poboljšanje kvaliteta života osoba podvrgnutih skriningu. 
Operativne mere obuhvataju procesne mere, kao i merenja rezultata i informacija dobijenih skrining programom. Ishodne mere ukazuju na to da li postoji korist za pacijenta. Neophodno je precizno definisati šta je korist za pacijenta i na osnovu kojih ishodnih mera se smatra da je dokazana. Navedene operativne i ishodne mere koriste se za pisanje izveštaja o sprovedenim aktivnostima, dok se za procenu daljih aktivnosti zdravstvenog sistema u cilju smanjivanja mortaliteta $\mathrm{i} / \mathrm{ili}$ incidencije koriste ishodne mere. Ove mere su neophodne i za procenu kvaliteta svakog koraka u organizovanom skriningu. Zbog toga je neophodno da je svaki korak skrininga detaljno objašnjen uputstvima kako bi organizacija skrininga na teritoriji jedne zemlje bila što uniformnija.

U našoj zemlji baza podataka, koja je potrebna za praćenje i evaluaciju skrininga, treba da sadrži podatke o ciljnoj populaciji, poslatim pozivima, odzivu, rezultatima testa, daljim dijagnostičkim i terapijskim procedurama [8-13]. Evidenciju poslatih poziva, uručenih poziva i odziva na testiranje vodi Tim za koordinaciju doma zdravlja. Navedene aktivnosti obavljaju se prema preporučenim standardima. Izveštavanje o rezultatima skrininga temelji se na setu podataka, koji se obavezno prikupljaju da bi se pomoću njih izračunali procesni i ishodni indikatori programa skrininga. Ti podaci nastaju u svakoj fazi skrininga pa je potreban standardizovan i koordinisan način njihovog prikupljanja u vreme kada nastaju. To omogućava standardizovan protokol (klinički put) u koji se unose svi traženi podaci i koji prati osobu u svim fazama skrininga. Protokol može postojati u papirnoj i/ili elektronskoj formi. Svi zdravstveni radnici koji učestvuju u sprovođenju skrininga imaju pristup protokolu, i svako od njih ispunjava svoj deo protokola. Podaci iz elektronske baze podataka doma zdravlja dostavljaju se jednom nedeljno nadležnom institutu / zavodu za javno zdravlje. Regionalni zavodi, jednom mesečno izveštavaju Kancelariju za skrining.

Kontinuirano unošenje i slanje podataka u elektronsku bazu podataka organizovanog skrininga obaveza je svih učesnika u skrining programu. Ažuriranje baze podataka obavlja Služba za informatiku Instituta za javno zdravlje Srbije. Kancelarija za prevenciju malignih bolesti periodično organizuje stručni nadzor i evaluira uspešnost sprovođenja skrininga za rak. Svi slučajevi raka koji su otkriveni skrining programom posebno se evidentiraju u Registru za rak (Centar za kontolu i prevenciju nezaraznih bolesti Instituta za javno zdravlje Srbije), kako bi se stvorili uslovi za procenu stopa incidencije raka sa slučajevima oboljenja koji su registrovani skriningom i onih bez skrininga.

\section{Studije za evaluaciju skrining programa}

Efektivnost nekog skrining programa se najčešće ispituje kohortnim studijama [17]. Dizajn kohotne studije za evaluaciju skrininga prikazan je na slici 2 . Skrining je efektivan ukoliko je umiranje od neke bolesti manje među osobama koje su podvrgnute skriningu nego među osobama koje nikada nisu bile podvrgnute skriningu. Umesto umiranja možemo pratiti obolevanje, kvalitet života, itd.

Poslednjih godina u cilju procene efektivnosti skrining programa sve češće se koriste anamnestičke studije (slika 3) [17]. Kod izbora kontrolne grupe treba biti obazriv, jer je važno da kontrolnu grupu čine osobe bez bolesti. Skrining se u ovim studijama posmatra kao faktor kojem su osobe mogle da budu izložene pre nastanka bolesti. Ako je skrining efektivan, očekujemo da ćemo pronaći veći procenat osoba podvrgnutih skriningu u prošlosti među kontrolama nego među osobama sa uznapredovalom bolešću.

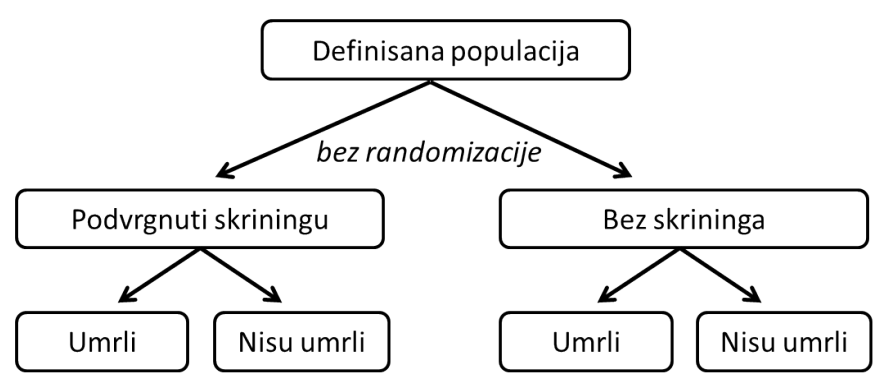

Slika 2. Dizajn kohortne studije za evaluaciju skrining programa [17].
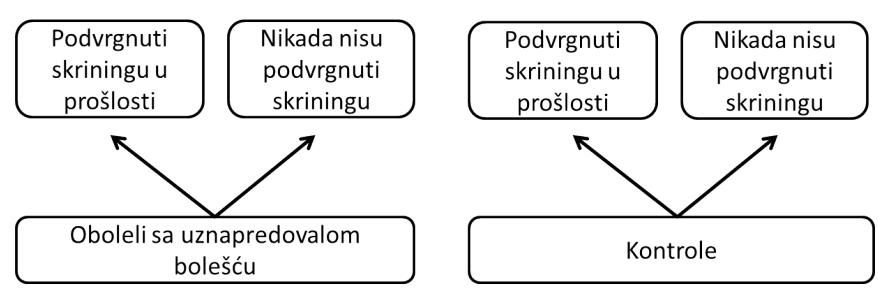

Slika 3. Dizajn anamnestičke studije za evaluaciju skrining programa [17].

Za evaluaciju skrining programa često se koriste i korelacione studije koje ispituju linearnu korelaciju između stopa obolevanja ili umiranja od nekog oboljenja i učestalosti primene skrininga. Ova veza može da se analizira upoređivanjem više populacija ili poređenjem jedne iste populacije u različitim vremenskim periodima. Najveći nedostatak ovih studija je što se podaci odnose na celokupnu populaciju, a ne na pojedince, pa nije moguće dokazati da je opadanje učestalosti umiranja 


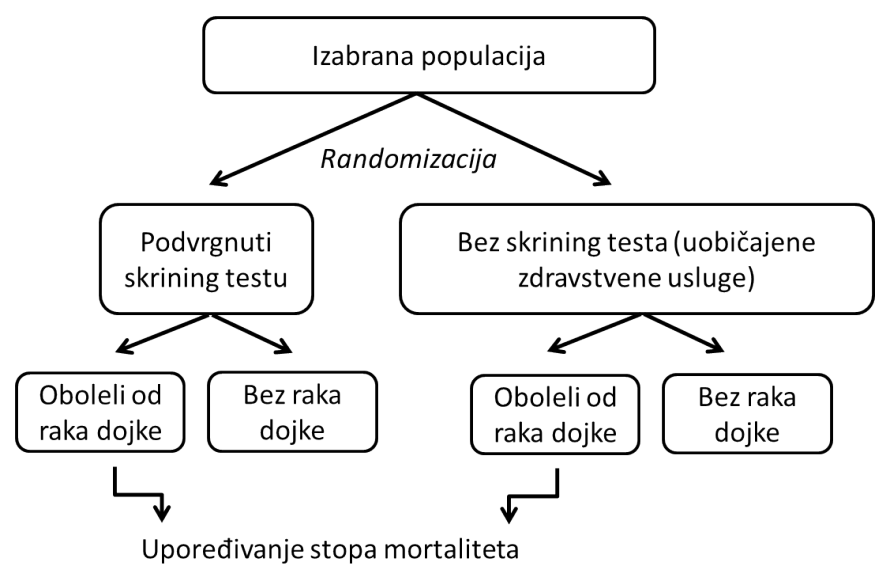

Slika 4. Dizajn eksperimentalne studije za evaluaciju skrining programa [17].

ili obolevanja prisutno samo kod osoba koje su podvrgnute skriningu. U korelacionim studijama nije moguća kontrola na potencijalne pridružene faktore, a uz to, učestalost skrininga predstavlja prosečnu vrednost za populaciju na osnovu koje nije moguće odrediti optimalnu skrining strategiju za pojedinca.

Najbolji dokaz o efektivnosti skrining programa daju eksperimentalne studije, ali se one retko sprovode jer su skupe ili postoji problem etičnosti. U randomizovanim eksperimentalnim studijama, ispitanici odabrane populacije se metodom slučajnog izbora razvrstavaju u eksperimentalnu (koja je podvrgnuta skriningu) i kontrolnu grupu (koja nije podvrgnuta skrinigu) (slika 4). Najpoznatija randomizovana studija je studija Shapiro-a i saradnika, izvedena 1963. godine [18]. Cilj ove studije je bio da ispita da li periodično korišćenje skrininga smanjuje mortalitet od raka dojke kod žena uzrasta 40-64 godine. Oko 62.000 žena Osiguravajućeg društva u Njujor$\mathrm{ku}$ je randomizacijom razvrstano u eksperimentalnu i kontrolnu grupu. Ženama u eksperimentalnoj grupi je ponuđeno da se povrgavaju skriningu jednom godišnje $\mathrm{u}$ naredne tri godine. Skrining se sastojao od fizikalnog pregleda, mamografije i upitnika. Kontrolna grupa je dobijala uobičajnu zdravstvenu zaštitu. Rezultati eksperimenta pokazuju da je skrining program bio efektivan jer je stopa mortaliteta od raka dojke bila manja u eksperimentalnoj nego u kontrolnoj grupi.

\section{Pristrasnost (engl. bias) pri evaluaciji skrining programa}

Pri evaluaciji skrining programa različite pristrasnosti mogu da utiču na odstupanje zaključaka od istine [15]. Pristrasnosti koje mogu da utiču na procenu efektivnosti skrining programa su: pristrasnost izbora, polazišna pristrasnost, pristrasnost usled različite dužine trajanja bolesti i informativna pristrasnost [17].
Pristrasnost izbora nastaje pri pogrešnom izboru populacije koja će biti podvrgnuta skriningu [15-17]. Ova pristrasnost je uslovljena uključivanjem dobrovoljaca u skrining program (volonterska pristrasnost). S druge strane postoji mogućnost da se neke osobe jave za učešće u skriningu jer imaju veći rizik za neko oboljenje, što znači da ove osobe imaju lošiju prognozu nezavisno od skrininga. Kod pristrasnosti izbora nikada ne možemo proceniti u kom pravcu ona deluje te kako može da utiče na rezultate skrininga.

Pristrasnost usled različite dužine trajanja bolesti može da nastane zato što je verovatnoća otkrivanja oboljenja skrinigom u zavisnosti od dužine trajanja presimptomatske faze bolesti [15-17]. Što je duža presimptomatska faza bolesti, to je veća verovatnoća da će se bolest otkriti skriningom. To znači da skrining vodi selektivnoj identifikaciji onih slučajeva koji imaju dužu presimptomatsku fazu bolesti, pa je samo prividno efektivan.

Polazišna pristrasnost je vezana za precenjivanje vremena preživljavanja i može da nastane usled pomeranja polazne tačke za određivanje preživljavanja unazad [15-17].

Informativna pristrasnost je u vezi sa pogrešnom klasifikacijom ispitanika na one sa negativnim i pozitivnim nalazom [15-17]. Npr. citolog koji čita Pap briseve može da svrstava zdrave žene u grupu žena sa pozitivnim nalazom.

\section{Rezultati jednog od organizovanih skrininga na području Beograda}

Organizovani skrining za rak dojke je započeo 20.12.2012. godine na području tri beogradske opštine (Lazarevac, Palilula i Stari grad) [19]. Ciljnu grupu činile su žene uzrasta 45-69 godina. Ukupan broj žena ciljne populacije, sačinjen prema broju žena koje su imale izabranog lekara opšte medicine u ovim domovima zdravlja, je bio 9.686 u Lazarevcu, 24.824 na Paliluli i 8.537 u Starom gradu. Rezultati organizovanog skrininga u navedenim opštinama Beograda u periodu 20.12.2012. do 31.12.2013. ukazali su da je pokrivenost pozivima za mamografiju bila $73,9 \%$ i da se $21,4 \%$ žena odazvalo i bilo podvrgnuto mamografiji, kao i da je prosečan obuhvat mamografijom iznosio $16,4 \%$. Procenat žena sa pozitivnim nalazom na mamografiji je bio $24,4 \%$, a na dopunsku dijagnozu je bilo pozvano 9,5\% pregledanih žena. Kod 13 žena je potvrđen karcinom dojke. Ovi podaci ukazuju da je teško sprovesti organizovani skrining na nacionalnom nivou, ali da i pored svih uočljivih nedostataka, prema dobijenim rezultatima, do sada je spašeno 13 života na području ove tri beogradske opštine, kada je reč o karcinomu dojke. 


\section{Zaključak}

Organizovani skrining je od ogromnog značaja za smanjenje incidence i mortaliteta od malignih tumora, ali je organizaciono veoma zahtevan što i potvrđuju do sada dobijeni rezultati. Neophodno je dalje raditi na osnaživanju organizovanog skrininga za rak dojke, rak grlića materice i rak debelog creva na područjima gde se skrining realizuje i uvesti ga na svim područjima naše zemlje gde postoje uslovi za njegovo sprovođenje.

\section{Literatura}

1. Zakon o zdravstvenoj zaštiti. Sl. glasnik RS, br. 107/2005.

2. Ministarstvo zdravlja Republike Srbije. Strategija za prevenciju i kontrolu hroničnih nezaraznih bolesti, 2008.

3. Ministarstvo zdravlja Republike Srbije. Nacionalni program borbe protiv raka, 2009.

4. Ministarstvo zdravlja Republike Srbije. Uredba o nacionalnom programu za prevenciju raka grlića materice, $\mathrm{Sl}$. Glasnik RS 54/2008.

5. Ministarstvo zdravlja Republike Srbije. Uredba o nacionalnom programu za prevenciju raka dojke, Sl. Glasnik RS $15 / 2009$.

6. Ministarstvo zdravlja Republike Srbije. Uredba o nacionalnom programu za prevenciju kolorektalnog karcinoma, Sl. Glasnik RS 20/2009.

7. Uredba o nacionalnom programu "Srbija protiv raka", Sl. glasnik RS", br. 20/2009.

8. Ministarstvo zdravlja. Uredba o nacionalnom programu za rano otkrivanje raka grlića materice. Sl. glasnik, br. 73/2013. Ministarstvo zdravlja. Uredba o nacionalnom programu za rano otkrivanje raka kolorektuma. Sl. glasnik, br. 73/2013.

9. Ministarstvo zdravlja. Uredba o nacionalnom programu za ranootkrivanje karcinoma dojke. Sl. glasnik, br.73/2013.

10. Ministarstvo zdravlja. Evropska unija. Institut za javno zdravlje Batut Republička stručna komisija za prevenciju i kontrolu raka grlića materice. Beograd, 2013.

11. Ministarstvo zdravlja. Evropska unija. Institut za javno zdravlje Batut Republička stručna komisija za prevenciju i kontrolu karcinoma dojke. Beograd, 2013.

12. Ministarstvo zdravlja. Evropska unija. Institut za javno zdravlje Batut Republička stručna komisija za prevenciju i kontrolu karcinoma kolorektuma. Beograd, 2013.

13. Australian population health development principal committee of the Australian Health Ministers' Advisory Council. Screening subcommittee. Population based screening framework. Australia: Commonwealth of Australia, 2008.

14. Radovanović Z (ur. jugoslovenskog izdanja). Epidemiološki rečnik. Drugo jugoslovensko izdanje. Beograd: Medicinski fakultet Univerziteta u Beogradu, 2001.

15. Vlajinac $\mathrm{H}$, Jarebinski M (urednici). Epidemiologija.Beograd: Medicinski fakultet Univerziteta u Beogradu, 2009.

16. Gordis L. Epidemiology, 4rd edition. Philadelphia: Elsevier Saunders, 2009.
17. Shapiro S, Venet W, Strax P, Venet L (eds). Periodic screening for breast cancer: the health insurance plan project and its sequelae, 1963-1986. Baltimore: Johnss Hopkins University Press, 1988.

18. Izveštaj Gradskog zavoda za javno zdravlje o rezultatima sprovedenog organizovanog skrining programa za rak dojke (nepublikovani materijal), 2013. 